\title{
Çocuk Kitapları İçin Karakter Tasarımından Kitap Tasarımına Deneysel Bir İllüstrasyon Uygulamas1
}

\author{
An Experimental Illustration Practice for Children's Books from Character \\ Design to Book Design
}

\section{Cem Kara}

Dr. Öğr. Üyesi, Marmara Üniversitesi Güzel Sanatlar Fakültesi Grafik Bölümü Grafik Anasanat Dalı, cmkr78@gmail.com

\section{$\ddot{O} z$}

Çocuk kitaplarının hayal gücünü geliştirme etkisi belirgin bir özellik olarak öne çıkmaktadır. Bu nedenle çocuk kitaplarını görselleştiren yaratıcı kişiden, önce çocuğun ilgi dünyasını yakalaması, sonra da kendine özgü anlatım dilini kullanarak yeni dünyalar tasarlaması beklenir. Böylelikle çocuğun ufkunun genişletilmesine önemli bir katkı sağlamış olacaktır. Çocuk, yetişkinlerin tersine çeşitli algı sınırları içinde henüz hapsolmuş değildir. Bu temiz bakış açısı resimleyen için sınırsız ve özgür bir yaratım alanını doğurur. Sanat ve tasarım alanında bu özgürlüğü kullanan yaratıcı kişiden sıradanlığın ötesinde özgün bir kişilik göstermesi aslında çok olağandır. Ancak yeni ya da farklı bir bakış açısı getirmek, resimleyenin denemeci tavrı ile oluşacaktır. Bir metinden yola çıkarak yeni bir dünya oluşturmak için öncelikle karakterleri tasarlamak, pratik bir yol olarak düşünülebilir. Karakterin biçim, renk, hareket ve mimik gibi unsurlarıyla ortaya çıkmış görsel kimlik, daha sonra elbette ki o karaktere ait çevrenin uyarlanmasıyla devam edecektir. Bir başka deyişle karakterle uyum içinde tasarlanacak bir çevre kurgusu kitabın özgün görsel kimliği olacaktır. Çocuk kitapları resimlemesi alanında bu özgün bir kimlik oluşturma, deneysel olma ve başlangıç noktası olarak karakterlerin tasarlanması üzerine Marmara Üniversitesi Güzel Sanatlar Fakültesi Grafik Bölümü Çocuk Kitapları Resimlemesi dersinde uygulanan örnek çalışma bu makalenin kapsamını oluşturmaktadır. Uygulanan proje iki temel aşamayı içerir. İlk aşama bir hayvan için üç boyutlu bir model oluşturulmasıdır. İkinci aşama üç boyutlu hayvan modeli baz alınıp resimlenmesinin oluşturulması ve özgün bir çocuk kitabının tasarlanma aşamasıdır.

Anahtar kelimeler: İllüstrasyon, Karakter Tasarımı, Çocuk Kitabı Tasarımı, Deneysel Tasarım, Özgünlük

\begin{abstract}
The effect of children's books on the development of imagination is a prominent feature. For this reason, the creative person visualizing the children's books is expected to first catch the world of interest of child and then design new worlds by using his own unique language of expression. Thus, he or she will make a significant contribution to the expansion of the child's horizon. Unlike adults, the child is not yet trapped in the limits of various perception. This clean point of view gives rise to an unlimited and free creation space for illustrator. In the field of art and design, it is very common for the creative person who uses this freedom to show a unique personality beyond ordinary. However, bringing a new or different perspective will be created by the experimental attitude of the illustrator. In order to create a new world from a text, firstly designing characters can be considered a practical way. The visual identity that emerged with elements such as form, color, movement and gesture of a character will then continue with the adaptation of the environment of that character. In
\end{abstract}


other words, an environmental construct designed in harmony with the character will be the original visual identity of the book. This is the case study of Marmara University Fine Arts Faculty Graphic Department Children's Books Illustrations course on this creating an original identity in the field of children's book illustrations, to be experimental and to design characters as a starting point. The applied project includes two basic stages: The first stage is the creation of a three-dimensional model for an animal. The second stage is to do illustration based on the creation of a threedimensional animal model and designing an original children's book.

Keywords: Illustration, Character Design, Children’s Book Design, Experimental Design, Originality

\section{Giriș}

Çocuk bakış açısı henüz biçimlenmemiş, temiz bir algıya sahiptir. Çeşitli deneyim ve yönlendirmelerle çevredeki nesneleri, olayları ve kavramları anlamlandırılma çabası gösterir. Bu yalın bakış açısı ilk zamanlar kendine özgü ifadeler ortaya koyarken, giderek genel anlayışın hakimiyetine girer. Nesnelere kendince isimler verme, oyunu kendi kurallarıyla oynamada olduğu gibi çevresini kendi çizgileriyle de anlatma bu duruma örnek davranışlar arasındadır. Elbette ki çocuğun gelişim evrelerinde temel edinimlerin kazanılarak büyüme doğal bir süreçtir. Ancak çocuğun çevresi ile olan ilişkisinde ve kavramları yorumlamasında yapılacak her türlü eğitsel amaçlı müdahalenin hassas bir dengede olması gerekmektedir. Resimleriyle kendi dünyasını ifade etmekte olan çocuğa herhangi bir yönlendirme yapılması, bu etkinliğin nasıl bir gelişim göstereceğini doğrudan etkileyeceği gibi, yaratıcı bakış açısının oluşumunu da dolaylı yönden etkileyecektir. Örnek verilecek olunursa; okul öncesi dönem çocuğu gerçekçi bakış açısının çok daha gerisinde göreli olarak hatalı çizimler gerçekleştirebilir. Yapılması gereken kendince anlatımları ortaya koyan çocuğun destek görmesidir. $\mathrm{Bu}$ şekilde kazanılan özgüven ile ilerleyen dönemde daha başarılı adımlar atılacaktır.

Gelişim evresinde edindiği bilgilerle kendi çözümlerini ortaya koyan bireyin her şeyden önce yaratıcı bir kimlik olarak yetiştirilmesi gerekmektedir. Bu konuda çocuk ve sanat arasındaki ilişki, problem ve çözüm arasındaki ilişkisi için etkili bir yöntem olarak gösterilebilir. Resim, çocuğun çevresini tanımlarken kullandığı işlevsel bir araç olduğu gibi, aslında bizzat kendisinin de kullandığı bireysel bir dildir. Gelişim ve yaratıcılık ilişkisini bir araya getirebilen bir uygulama alanıdır. Resim ve çocuk arasındaki ilişkisi basit ifade ile fiziki dünyanın kavranmasıyla ilişkilendirilebileceği gibi pek tabii ki yaratıcılık, dolayısıyla düşünmeye dair gelişimle de ilişkilendirilebilir. Çocuk ve gençlik psikolojisi uzmanı Yavuzer, resim ve gelişim konusundaki düşüncelerini şu sözlerle özetlemektedir;

Yapılan resim üzerinde yetişkinden gelebilecek bir uyarı ya da olumsuz eleştiri çocuğun eylemi sona erdirmesi için yeterli neden olabilir. Çünkü resim etkinliği başarılmış eylemler yönünden gelişme eğilimindedir. Modern pedagoji açısından en iyi yazan çocuk; çok sayıda sözcügü doğru yazan, cümleleri gramer kuralarına göre kuran değil, sözcükleri kişisel cümlelerde yaşatanlardır. Bu cümleler çocuğun düşünce ve yaşamını ifade ederler. Resim konusunda da en gelişmiş çocuk da okul isteğine ve perspektif kurallarına uyan değil, resimdeki kişi ve objelere yaşam veren çocuktur. İşte biz bu eylemi desteklemeliyiz, yardım etmeliyiz, değer vermeliyiz ki çocuk başarı ve güvence elde etsin (Yavuzer, 2018, s. 84).

Çocuk resmi kısıtlamalara bağlı değildir, çoğunlukla orantısızdır. Ancak gelişim evreleri içinde zamanla daha doğru oran-orant1, büyüklük ve ön-arka ilişkisi kurulmaktadır. Gerçekçi görünümün temel unsurlarından biri olan perspektif onların resminde aranmaz. Cesaretle uygulanmış çizgiler, 
şekiller ve renkler bulunmaktadır. İçerikte de birçok kişisel veriler kendini gösterir. Stilizasyon ve deformasyon en çok izlenen görsel anlatım yöntemlerindedir.

Çocuk resmi öz bakımdan realist olsa bile, çizgilerinde realizme zıt iki eğilim görülür. Bunlar; şematizm ve idealizmdir. Şematizm, objenin nitelik ve nicelik detaylarını koruyarak basite indirgeyen bir çizim şeklidir. Birçok çocuk, resimlerini bu şekilde oluşturur. İdealizm ise objenin dış karakterlerini zenginleştirmeye dayanır. Yansıtılan nesnenin, olağanüstü çizgiler katılarak ya da dekoratif renklendirme uygulanarak görünümü değiştirilir, çocukça deyimle güzelleştirilir (Yavuzer, 2018, s. 73).

Öztop da çocuk resminin görsel dilini şu şekilde açıklamaktadır; "Henüz bakir, çıplak olan çocuk gördüğünü 'anormal' olarak görür. Bu gerçek üstüdür, bir çeşit Sürrealizm'e yaklaşır. Çocuk resimlerinin ilginçliği, beklemedik biçim ve renklere bürünüşü bu özelliğin ürünüdür. Nesneler, uzaklık ve yakınlıklar çocuğun gözünde normal dışıdır” (Öztop, 1985, s. 17).

Çocuğun şekilleri ve renkleri bu derece kuralsız bir biçimde, içinden geldiği gibi, doğal sezgilerle kullanması aynı zamanda yaratıcı kimselerin de dikkati çeken bir unsurdur. Plastik araçları kullanan sanatçılar için bu özgür yapı doğaya alternatif bir denge oluşturmada öykünülen bir alana dönüşebilmektedir. Bu açıdan bakıldığında çocuk resminin dili ile sanatçı dilinin yakın derecede kesiştiği, hatta iç içe geçtiği alan olarak resimli çocuk kitapları gösterilebilir. Resimli çocuk kitapları, çocuksu algının izleri ile yaratıcı görüşünün harmanlandığı bir dünyadır. Resimleyen, çocuk resminin dilini kullanarak hem çocuğa yakın bir yol izleyebilir hem de bu yöntemle önünde sınırları sonuna kadar zorlanabileceği bir alan yer alabilir. Çocuk resmindeki bu özgürce kullanım anlayışı, çocuk diline uygunluk olduğu gibi çevrenin özgürce anlatımı yaratıcılı̆̆ 1 geliştirmek için bilinçli bir resimleme diline de dönüştürülebilir. Sever, çocuk kitaplardaki sanatsal yaklaşımın önemini ve çocuk diline uygunluğu şu sözlerle anlatmaktadır;

Çocuk resimlerde hem kendi gerçekliğiyle buluşabilmeli hem de çizginin ve rengin yarattığ güzelliklerle mutlu olmalıdır. Çocuğun beğenisini sanatsal bir dille okşayan, onun sürekli yeni şeyler öğrenme, tanıma gereksinimlerine yanıt veren resimlerin, çocukların duygu ve düşünce eğitimine de önemli katkılar sağlayacağı söylenebilir. Özellikle, sanatsal biçemle oluşturulmuş bir resmi, çocuk kendi imgelemlerinde tamamlama çabaları, bilişsel ve duyuşsal içerikli birçok davranışın edinilmesi sürecini başlatır (Sever, 2018, s. 173).

Çocuk kitapları bilişsel, duygusal ve hatta sosyal gelişim yönünden çeşitli kazanımlar sağlamak için etkili bir araç olarak kullanılır. Yaş gruplarına göre resimleme ve metinler arasındaki ilişki, metinlerin giderek daha fazla kullanıldığı bir süreci izlemektedir. Metinler kelimelerden cümlelere, cümlelerden paragraflara doğru gelişiriken, resimlemeler de yine yaş gruplarına göre basit formlardan detaylı çalışmalara doğru biçimsel bir gelişim gösterirler. Özellikle okul öncesi dönemdeki kitaplarda resimlemeler içeriğin büyük bir kısmını oluşturur. Bu dönemde yaratıcı bakış açısı ve duyarlılığı oluşturacak olan resimlemeler çocuğun aynı zamanda çevresini anlamlandırma sürecinde yoğun olarak kullandığı araçlardır. Bu nedenle gelişimsel açıdan görsel içeriğin kapsamı, nasıl oluşturulduğu, yenilikçi bir söyleme sahip olup olmadığı hassas bir şekilde ele alınmalıdır. Bu noktada Tuğrul ve Feyman, kitaplardaki görsel içeriğin önemi ve niteliği üzerine şu tespitleri yapmaktadır;

Okul öncesi çocuğu henüz okuma yazma bilmediği için kitaptaki resimlerin çocuğun zihninde anlam yaratabilecek kadar somut ancak hayallerini besleyecek kadar kışkırtıcı ve heyecan verici olması gerekir. Resimli öykü kitapları taşıdıkları görsel özellikler nedeniyle çocukların duygularını, düşüncelerini ve algılarını harekete geçirirler. Bu bir anlamda resimlerin çocukla konuşması demektir (Tuğrul ve Feyman, 2006, s. 388). 
Çocuk kitaplarında resimlerle öncelikle çocuğun dikkati çekilmelidir. Sonrasında çocuğun yeni sorular ve yeni cevaplarla karşılaşması sağlanmalıdır. Yaratıcı içerik ile düşünme pratiğini kuvvetlendirmek için sanatsal anlayış ile üretilmiş çalışmalara yaklaşmak gerekir. Bu konuda Aşılıoğlu'nun Özer'den yaptığı bir alıntıya yer verilebilir;

Yakın bir zamana kadar çocuk kitaplarında resimlerin temel işlevinin, sadece bakma edinimi sonrasında görünen anlamın kavranması olduğu kabul edilmekteydi. Günümüzde ise resmin artık görünenden başka bir şey, anlamsal bir bütün olduğunu anlayışı yaygındır. Bu anlayışa göre, ne sadece eserin dış güzelliği ne de sadece öz güzelliği tek başına yeterli olmayacaktır. Bu nedenle çocuk kitabı resimleyen sanatçı, resimlerini anlam ve iletileri ile sanatsal bir kaygı bütünü olarak yaratmalıdır (Aş1lığlu, 2011, s. 69).

Sanatsal kaygının temelinde her şeyden önce özgünlük ilkesi yatmaktadır. Diğer bir deyiş ile sanatsal duyarlılık ya da kaygılarla ele alınan konularda kişisel yaklaşımların izleri görülmektedir. Amaç; özgün çözümler ortaya koymak için, tekrar etmenin ötesinde kişisel yaklaşımları kullanmaktır. Çocuk kitapları alanında da resimleyenin kişisel bir dil göstermesi özgün üretimleri çoğaltmakta ve dolayısıyla bu yaratıcı içerik ile çocuğun düşünmeye yönelik yönünü beslemektedir. "Resimlemeyi yapan çizer, metinden yola çıkarak tasarladığı sahnenin görüntü yönetmenidir. Tipleri belirler, mekanı oluşturur, bakış açısını kararlaştırır. Bütün bu elemanları uygun, armonik bir bütünlük içinde bir araya getirmesindeki kendine haslıktır resmi tek ve kalıcı yapan" (Kaya, 2006, s. 421). Kendisi de çocuk kitapları illüstratörü olan Kaya, çocuk kitabında kişisel yaklaşımın tanımını bu şekilde yaparken, Şahin'de düşünme eylemi ve resimleme ilişkisi üzerine şu tespitleri yapmaktadır;

Çocuğa kitabın daha en başında duyma ve düşünme sorumluluğu yükleyen sanatçı, onu kendi özgün dünyasına çeker ve düş gücünün sınırlarını zorlar. Her sayfasında "Acaba ne olacak?" sorusuyla sürekli görsel bir uyaran olarak işe koşulan resimler, çocuğun düşünmesine, sorgulamasına, akıl yürütmesine ve çıkarımlarda bulunmasına yardımcı olur. Renk ve çizginin ardına saklanmış doğa sevgisi, insan sevgisi, yaşama sevgisi gibi insana özgü durumlar, çocuğu düş kurmanın yanı sıra düşünsel bir çaba içine sürükler (Şahin, 2013, s. 1315).

Görüldüğü üzere nitelikli çocuk kitaplarının gelişim üzerindeki etkisi son derece önemlidir. Bu alan, günümüzde, beklentiler, teknoloji kullanımında yaygınlaşma ve sanatçıların ilgisi ile başlı başına büyük bir sektör haline dönüşmüştür. Sektörün genişlemesi, sıradanlığı ya da benzer üretimler tehlikesini de beraberinde getirmektedir. Ancak söylendiği gibi illüstratör için çocuk kitapları, diğer resimleme alanları içinde belki de en özgür alandır. İllüstratör, çocuk kitaplarında içeriği de dikkate alarak deneyselliğin sınırlarını zorlayarak yaratıcı ve dolayısıyla özgün çalışmalar ortaya koyabilir. Deneysel çalışmalar hem özgün bir dil oluşturulmasında hem de yeni örneklerle alanın geliştirilmesinde önemli bir yere sahiptir. Bu açıdan, deneysellik adına birçok farklı yaklaşım sergilenebilir. Uygulama tekniklerinin sınırları zorlanabileceği gibi, yeni renk ilişkileriyle sıradanlıklar bozulabilir ya da kompozisyon adına alışılımışın dışında denemeler yapabilir. Peki, başlı başına karakter tasarımında yapılacak biçimsel denemeler, yeni bir anlatım dilinin ortaya çıkmasını sağlayabilir mi? Diğer bir deyiş ile kitabın görsel dilini etkileyecek olan karakter tasarımında deneysel bir yaklaşım sergilene bilinir mi? Karakter tasarımından yola çıkılarak özgün çocuk kitapları üretile bilinir mi?

\section{Yöntem}

$\mathrm{Bu}$ çalışma, çocuk kitapları resimlemesine ilgi duyan öğrencilerin, deneyselliği kullanarak yaratıcı, dolayısıyla özgün üretimler ortaya koyması için gerçekleştirilmiştir. Öğrencilerin, ürettikleri eserler ile kişisel anlatım dillerinin gelişiminde yeni sorular keşfetmesi ve bu sorular ile gelişimin ivmelendirilmesi hedeflenmiştir. $\mathrm{Bu}$ amaç ve hedeflerle gerçekleştiren çalışma bir eylem 
araştırmasıdır. Akademik araştırma yöntemlerinden biri olan eylem araştırması özetle halihazırdaki uygulamaların verimini arttırmak ve ilerleme kat etmek amacıyla gerçekleştirilir. Aksoy bu konuda O’Brien'dan yaptığı bir alıntıda yöntemin tanımını "bir grup insanın bir problemi tanımlaması, problemi çözmek için bir şeyler yapması, çabalarının ne kadar başarılı olduğunu görmesi, eğer sonuçtan tatmin olmazlarsa yeniden denemesi kısaca, yaparak ve yaşayarak öğrenmesidir" (aktaran Aksoy, 2014, s. 477) şeklinde aktarmaktadır. Bu tanımla ilişkilendirdiğimizde, "deneyimleyerek öğrenme" amaciyla gerçekleştirilen ve resimlemeye yönelik olan bu çalışma 2016-2017 Eğitim Öğretim Yılı'nda Marmara Üniversitesi Güzel Sanatlar Fakültesi Grafik Bölümü Çocuk Kitapları İllüstrasyonu dersi kapsamında uygulanmıştır. Çalışma grubu dersi alan üçüncü ve dördüncü sınıf öğrencileri arasından oluşmaktadır. Makalede çalışmaya dair detaylara geçmeden önce çocuk kitapları alanında geleneksel yöntemlerin dışında (veya kombine ederek) malzeme odaklı çalışan illüstratörlere ait örnek uygulamalar / görsel anlatım dilleri incelenmektedir. Bu incelemedeki amaç deneysellikle ilgili bakış açısının örneklerle pekiştirilmesidir. Araştırmanın uygulama bölümünde ise iki temel aşamanın olması ön görülmüştür. Çalışmaya bir hayvan karakterinin tasarlanması ile başlanmış, bu kapsamda "hazır malzeme ile üretim" uygulama yöntemi olarak seçilmiştir. Her malzemenin kendi kullanım olanakları düşünülmüş ve ortaya çıkacak tesadüfiliklerin özgünlük için temel oluşturması hedeflenmiştir. Elde edilen sonuçlar ilerleyen süreçte kontrollü bir resimleme diline çevrilmesi sağlanmış, projenin tamamında karakter tasarımından çocuk kitabı tasarımına doğru bir süreç izlenmiştir. Çalışmada hazır metinler yerine öğrencilerin kendi hikayelerini yazması istenmiş, metinlerin işlevi, resimlemelerin metinleri nasıl ve hangi açılardan tamamladıklarının gözlemlenebilir olmasıyla sınırlı tutulmuştur. Sonuçlar daha önceki yıllarda aynı dersi alan farklı öğrencilerin çalışmaları ile karşılaştırılmıştır. Elbette ki çalışmanın sonuçları bir sonraki uygulama için veri oluşturmuş ve gelişime yönelik yeni bir çalışmanın yapılması planlanmıştır.

\section{Bulgular ve Yorumlar}

\section{1. Çocuk Kitapları İllüstrasyonu ve Deneysellik}

Çocuk kitapları sektörü büyüdükçe özellikle resimleyenler arasında da rekabet artmaktadır. Bununla birlikte, sektör, yenilikçi yönü ile belirgin bir akım yaratabilmiş ya da başarısı kanıtlanmış çalışmaların tekrarını isteyebilmektedir. Bu durum tüketimi hızlandırdığı gibi sıradanlaşmayı da beraberinde getiren bir anlayıştır. Yaratıcı kişiler aksine şartlanmalardan uzak durup özgün bir kimlik oluşturarak sektör içinde kalıcı olabilmektedirler. Alanın yeni açılımlar yaparak büyümesi ve çocuğun zihinsel aktivitesinin çeşitlenebilmesi adına farklı görselleştirme anlayışlarının destek görmesi önemlidir.

Resimleyene ait özgün kimlik ancak yoğun bir çalışma ve dolayısıyla deneme süreci sonucunda gerçekleşebilir. "Yaratıcı kişiler algıları açı ve çevrelerine karşı dikkatli olurlarken, deneyimlerinin ve sezgilerinin yardımıyla hızlı dışavurumlar gerçekleştirirler. Yaratımlarında tesadüf olanı avantaja çevirebilirler. Özgünlüğü 'değişmez' olarak ele alırlar” (Kara, 2017, s. 192). Özgün bir kimliğin elbette ki etkileşimden uzak, her yönü ile farklı biçimde ortaya konması beklenemez. Yaratıcılıkta etkilenme ile kişisel tercihlerin cesaretli bir şekilde harmanlanması öne çıkmaktadır. Uygulama yaparken çalışmayı başkalaştıracak olan çeşitli etkenleri sürece dahil etmek, denemek yeni sonuçları doğuracaktır. Teknolojik gelişmelerin, dönemsel eğilimlerin takip edilmesi, fikir paylaşımlarında bulunulması, kritik alınması, düzenli çalışma için motivasyon yaratılması ve sabır gösterilmesi özgün dilin gelişimi için önemli süreçlerdir. Ancak bu noktada cesaretli olma ya da inisiyatif kullanabilme davranışları daha çok karşımıza çıkmaktadır. Denemeci olmanın önündeki en büyük engel hata yapma korkusudur. Uygulama üzerinde cesaretli davranma, aslında uygulamanın olanakları bağlamında bir takım tesadüfüliklerin ortaya çıkmasına izin vermektir. Bir başka deyişle kendiliğinden beliren 
tesadüfi sonuçları görüp, bilinçli bir anlatıma dönüştürebilmek uygulama üzerinde inisiyatif kullanmanın bir getirisidir.

Her çalışmayı bir süreç olarak görme, tesadüfilikleri olumlu bir noktaya dönüştürebilmenin dışında renk, form, teknik ve kompozisyon bakımından da alışagelmiş uygulamaların dışına çıkma isteği denemeci anlayışın uygulama aşamasındaki bir başka yönelimidir. Resimleyen renk kullanımını çocuğun ilgisini yakalayacak bir unsur olarak kullanmayı tercih ederken, farklı renk ilişikleri, yan yana gelme olasılığı düşük birliktelikler ile içeriğin sınırlarının genişletilebileceği veya farklı duygusal durumlar yaratılabileceği unutulmamalıdır. Biçimin ortaya konması ise başlı başına sadece kişisel tercihlerle gerçekleştirilebilecek, sınırları en az olan uygulama alanıdır. Diğer taraftan her illüstratörün sonuçlarından haz duyduğu bir uygulama yöntemi vardır. Bununla birlikte tekniğin kişisel uygulama biçimlerine adapte edilmesi ve farklı yöntemlerin kombine edilerek yeni görsel dünyalar yaratılması belki de denemeci anlayış bakımından günümüzde en çok tercih edilen yaklaşımlardır.

\section{2. Çeşitli İllüstratörlerden Örnekler}

Baskı resim teknikleri her ne kadar geleneksel yöntemler arasında görülse de, bu yöntemlerle elde edilen plastik yapı ve özellikle tekniğe has dokusal değerlerin çocuk kitaplarındaki kullanımı bugün dahi deneysel çalışmalara örnek gösterilebilir. Bununla birlikte baskı resim teknikleri ile dijital uygulamaların bir arada kullanımı ve baskı resim tekniklerinde elde edilen dokusal değerlerin dijital ortamdaki tekrarı da çağdaş uygulamalarda sıklıkla yer almaktadır.

Görsel 1'de Güney Kore kökenli ABD'li illüstratör JooHee Yoon'un, DH Lawrence, Lewis Carroll ve Hilaire Belloc gibi yazarlarca kaleme alınmış ve bir hayvan şiirleri koleksiyonu olan 'Beastly Verse' isimli kitap için cesurca resimlediği çalışmalardan biri yer almaktadır. Yoon, bir röportajında "bu çalışmasını şiirde de görülen ritim ve şakacılığı doğal olarak çizebilen çocuklarla paylaşmak istediğini” belirtmektedir (Yoon, 2015). Yoon'un çalışmasında geleneksel baskıresim teknikleri ile dijital uygulamaların bir harmanı yer almaktadır. Yoon kişisel anlatım dili olarak baskıresim tekniklerinin uygulama sınırları içinde ortaya çıkan görsel dili kullanmakta ve az, ancak güçlü renklerle etkili bir dünya oluşturabilmektedir. İki rengin birleşiminden çıkan üçüncü renk kullanımı, belirgin bir kişisel dili olarak dikkati çekmektedir.

Görsel 2'de İtalyan illüstratör, Chiara Carrer'in 2011 yılı Bologna Çocuk Kitapları Fuarı Ragazzi Ödülleri Yeni Ufuklar kategorisinde Özel Mansiyon alan "Un Dia” (Bir Gün) isimli kitapta yer alan bir çalışması görülmektedir. Carrer'in de aynı Yoon gibi uygulama biçimi geleneksel bir yöntem olan ve modernist yaklaşımın kuvvetli dili olarak bilinen "kolaj”1 seçtiği görülmektedir. Kolaj yöntemi de günümüzde hem geleneksel anlamdaki kullanımı hem de dijital ortamdaki uyarlamaları ile çağdaş bir yöntem olarak kullanılmaya devam edilmektedir. Günümüzde üretilen resimlemeler incelendiğinde de kolaj tekniğinin aynı zamanda deneysel anlayışın sergilenebileceği en uygun yöntemlerden biri olarak karşımıza çıktığı görülmektedir. Carrer, "zaman içinde ürettiği veya biriktirdiği kâğıt parçaları, kartlar, semboller ve benzeri hazır malzemeleri çalışmasının ihtiyacına göre uyarlayarak" yaratıcı karakter tasarımlarıyla başarılı bir şekilde birleştirdiği anlaşılmaktadır (Carrer, 2016). 


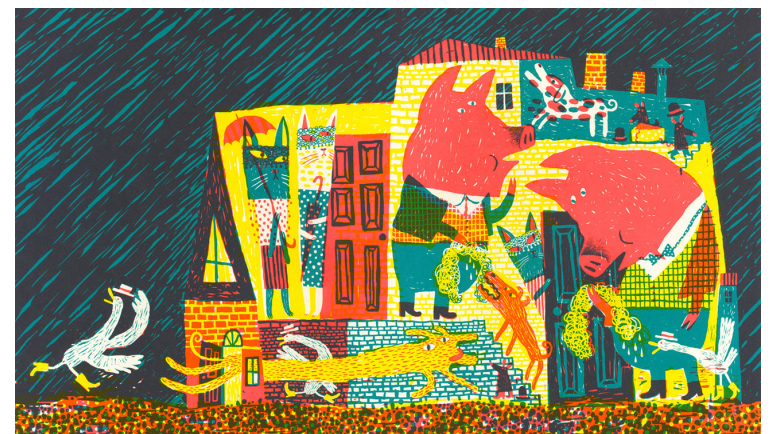

Görsel 1. "Beastly Verse" kitabindan bir resimleme, JooHee Yoon, 2015.

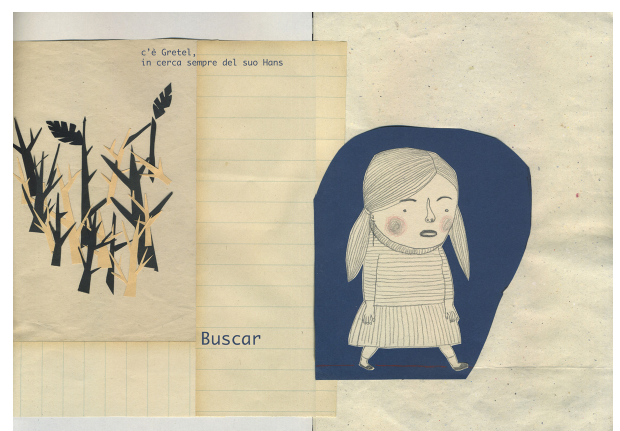

Görsel 2. "Un Dia” kitabindan bir resimleme, Chiara Carrer, 2010.

İsveç'li illüstratör Malin Koort ise kağıtları üç boyut etki yaratacak şekilde kullanmayı tercih etmektedir. Koort'un Görsel 3'de yer alan çalışması, 2011-2018 yılları arasında gerçekleştirdiği ve "Kâğıt İnsanlar" olarak çevrilebilecek kişisel çalışmalarından birisidir. Koort bir röportajında "fotoğraf çekerken sadece yakınlaşılarak ve 1şı̆̆ın yönünü değiştirerek çeşitli duygu durumları yaratmaktan hoşlandığını belirtmektedir” (Koort, 2018)

Isidro Ferrer, aslen Drama ve Set Tasarım Bölümü’nden mezun olan dünyaca ünlü bir İspanyol illüstratördür. Ferrer'in özgün anlatım kimliği üzerine yazılan bir internet yazısında "şaşırtıcı içeriğin göstergesi olarak kullanılan gündelik nesnelerin fotoğrafla birleşmesi sürreal bir görünümü ortaya koyduğu, bu nesnelerle insanlaştırılmış ya da hayvanlaştırılmış özgün karakterler yarattığı" belirtilmektedir (Isidro Ferrer, 2018). Görsel 4'de yer alan "Una Casa Para el Abuelo" isimli kitap içindeki çalışmasında da görüldüğü üzere Ferrer adeta bir sahne tasarlıyormuşçasına kullandığı ahşap, metal ve diğer malzemeleri kullanarak üç boyutlu formlar oluşturduğu görülmektedir.

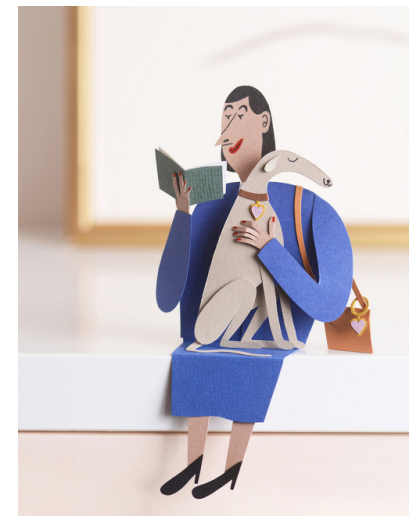

Görsel 3. "Paper People" kişisel çalışma, Malin Koort, 2011-2018.

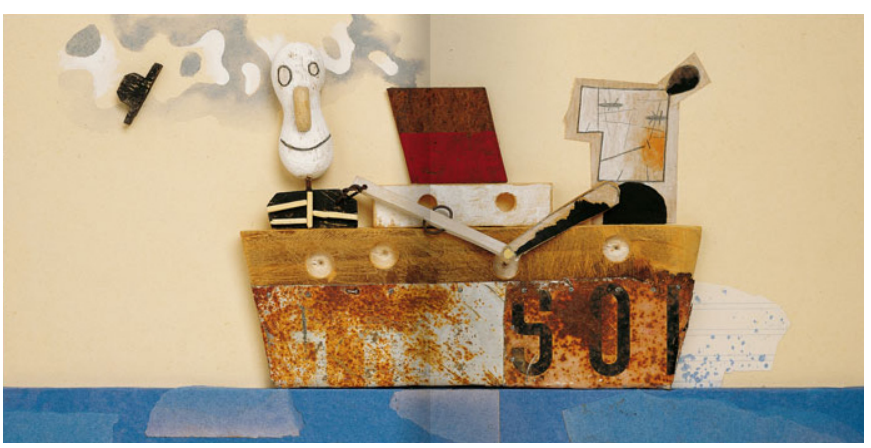

Görsel 4. "Una casa para el abuelo" kitabindan bir resimleme, Isidro Ferrer, 2016.

Görsel 5'de eserlerini Red Nose Studio adı altında üreten ABD'li illüstratör Chris Sickels'e ait bir çalışma yer almaktadır. Bu çalışmada da sahne ortamı tasarlanarak ortaya konmuş bir resimleme görülmektedir. "Here Comes The Garbage Barge!" İsimli kitaptan bir sayfa olan görsel, Sickels'e ait kişisel anlatımın tüm özelliklerini yansıtmaktadır. Sickels bir blog yazısında bu kişisel tarzına ait detayları verirken; "tel, köpük, polimer kil, elle dikilen giysiler için kumaşlar, tahta, kağıt, boya gibi bir çok malzeme kullandığını ve bu malzemelerle en uygun sahneyi fotoğraflamak için sayısız deneme yaptığını" belirtmektedir (Newman, 2018). Sickels'in anlatım kimliğinde abartılı karakter tasarımlarını oluşturan malzemeler dikkati çekmekle birlikte aynı zamanda sahnenin fotoğraflanma açısı ve ön-arka planlar arasındaki derinlik algısı da ön plana çıkan uygulama yöntemleri arasında gözükmektedir. 
Görsel 6'da da temel malzeme olarak polimer kil kullanıp 3 boyutlu figür ve sahne detayları oluşturan bir illüstratör yer almaktadır. Çalışma, "Design by Toko" tarafından tasarlanan ve 2017 yılı AGDA ödüllü (The Australian Graphic Design Association), "My Sister is a Martian" isimli kitap için yapılmış illüstrasyon çalışmalarından biridir. Kanadalı illüstratör ve animasyon sanatçısı Hudson Christe bu çalışmada izlenen yaklaşım tarzını açıklarken "stop-motion animasyonları izleyerek büyüdüğünü, ahşap oyma heykel sanatının sadeliğinden etkilendiğini, çalışmalarına bu tarzı taşımaya çalıştığını belirtmektedir. Christie, son tarihi olan işleri yetiştirmek için hızlıca çalıştığını ve bu durumun tarzının ortaya çıkışını kolaylaştırdığını, ayrıca etkilendiği çalışmalardan daha fazlasını yeni bir kimlik olarak ortaya koyabildiğini” belirtmektedir (Ball, 2015).

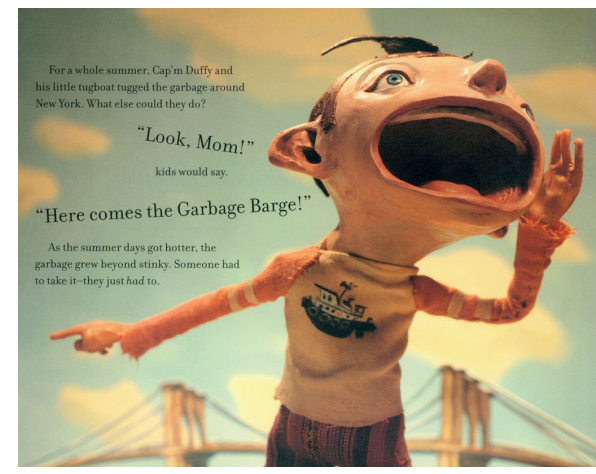

Görsel 5. "Here Comes The Garbage Barge!" kitabindan bir resimleme, Red Nose Studio - Chris Sickels, 2010.

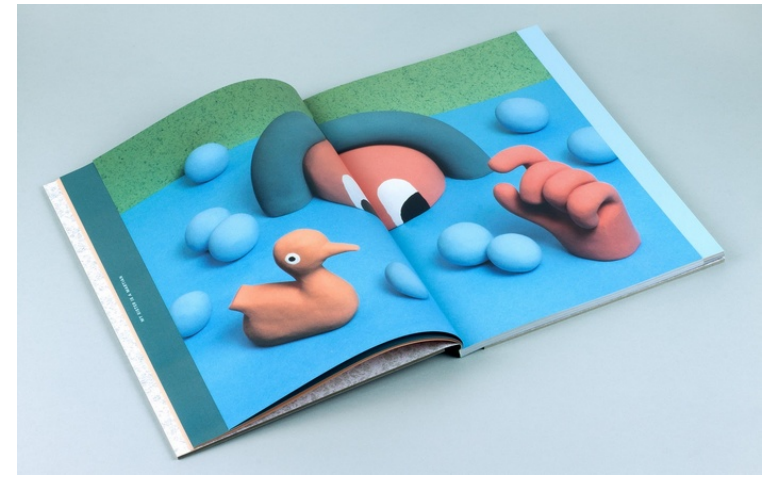

Görsel 6. "My Sister Is a Martian" kitabindan bir resimleme, Hudson Christe, 2017.

İngiliz illüstratör ve animasyon sanatçısı Jack Sachs de üç boyutlu tasarım programlarını kullanarak çalışmalarını üretmektir. İşlerinin genel karakteristiği polimer kil ile üretilen üç boyutlu tasarımların sanki dijital ortamdaki uyarlaması gibidir. Görsel 7'de kişisel çalışması yer alan Sach'in gerçeklik ile sanal olan arasında, güçlü bir stilize bir yaklaşım ortaya koyduğu söylenebilir. Sachs, gerçeküstü görüntüleri dijital ortamda etkili bir şekilde oluşturan genç kuşak temsilcilerindendir. Her yıl Berlin'de gerçekleştirilen ve güncel karakter tasarımı anlayışlarının paylaşıldı̆̆ı bir sempozyum olan "Pictoplasma"da konuşmacı olarak yer almıştır. Pictoplasma, 1999 yılında temelleri atılan ve karakter tasarımı alanında kâr amacı gütmeyen önemli bir oluşumdur. Bir blog yazısında Pictoplasma'nın önemi şu şekilde vurgulanmaktadır;

Karakterlerin karikatürlerden, grafik romanlardan, amatör animasyonlardan, reklam çalışmalarından çıkıp tam bir sanat dalı haline gelmesinde, saygınlaşmasında onların payı büyük. Hatta tek başlarına, çabalarıyla karakter tasarımını soylulaştıran güç odağı oldukları bile söylenebilir. Pictoplasma bugün bir karakter yaratım santrali adeta. Hatta bir taşeron. Sanatçıların işlerini toplayan ve dağıtan, onların isminin duyulmasını, giderek sektörün aradığı tasarımcılar halini almalarını sağlayan bir aracı kurum (Aysel, 2011).

Deneysel çalışma yöntemleri konusundaki son örnek stilize çizim tavrını mizah ile birleştirebilen Alman kökenli ABD'li illüstratör Christoph Niemann'dır. Niemann, öne çıkan çalışmalarındaki karakterlere hayat vermek için hazır nesneleri kullanmakta, bunlara firça ile küçük fikirsel müdahaleler ekleyerek yeni imgeler yaratabilmektedir. Görsel 8'de "Sunday Sketching" adl1 çalışmalarından oluşan seçki kitabının bir sayfası görülmektedir. Niemann'ın bu mizahi yaklaşımı Heller tarafından yazılan bir blog yazısında şu şekilde anlatılmaktadır; 
Gelip geçiciliğin ötesinde, belirli bir anın özünü yakalayabilen editoryal resimlemeler üretmek, soyut göstergeleri izleyicinin duygularını ve aklını zorlayacak biçimde etkileyen işaretlere, anlamlara, sembollere, karakterlere ve kavramlara dönüştürmek, doğru görüntüyü doğru sonuç için doğru zamanda kanalize etmek için özel bir yaratıcı çeviklik gerekir. Christoph Niemann'a bu yetenek verilmiştir (Heller, 2017).

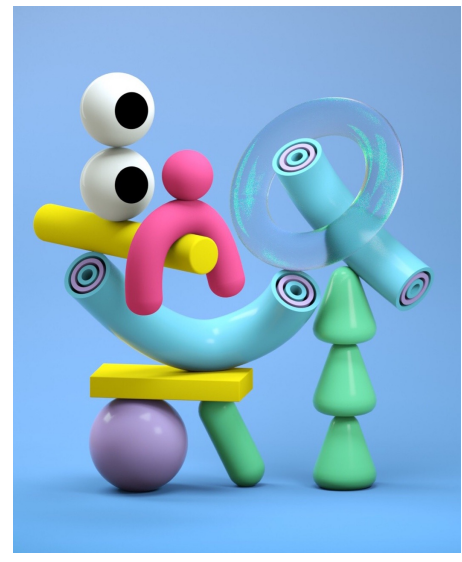

Görsel 7. Kişisel çalışma, Jack Sachs, 2018.

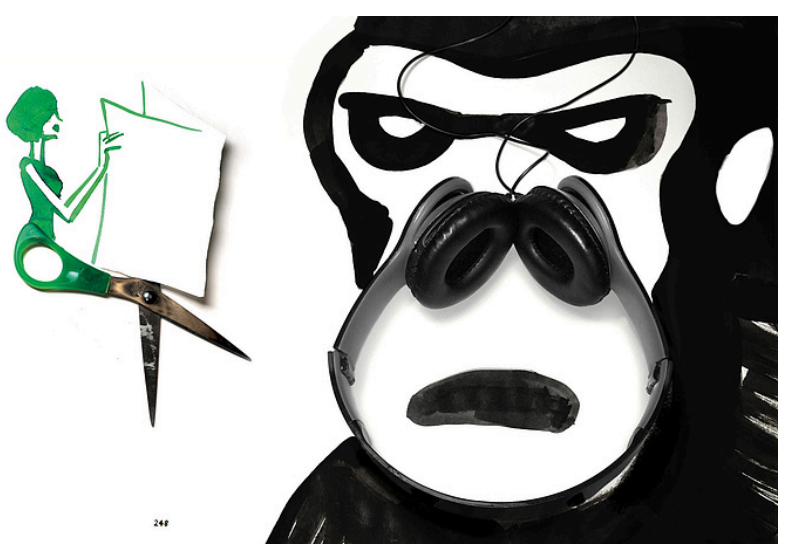

Görsel 8. "Sunday Sketching” kitabindan bir resimleme, Christoph Niemann, 2017.

\subsection{Deneysel Bir Uygulama Örneği}

\subsubsection{Karakter Tasarımı}

Plastik sanatlarla ilgili uygulamalarda deneysel anlayış ve tesadüfilik arasında yakın bir ilişki vardır. Deneysel çalışmalardaki amaç; süreç içinde ortaya çıkabilecek tesadüfi oluşumlara izin vermek, bunları detaylı bir şekilde gözlemlemek ve elde edilen sonuçları bilinçli bir uygulama ya da düşünme metoduna çevirebilmektir. Bu tespitten de yola çıkarak, resimli çocuk kitapları alanında gerçekleştirilen projeye, bütünü etkileyecek olan ve tesadüfi sonuçların alınabileceği düşünülen yöntemlerle çalışılarak başlanmıştır. Deneysel yöntemler karakter tasarımının ortaya çıkartılması için kullanılmıştır. İlk aşamada hazır malzemelerle üç boyutlu hayvan modellerinin oluşturulması istenmiş, her öğrenci kendi seçtiği bir yöntem ve malzeme ile yine kendi seçtiği bir hayvanı yorumlamıştır. Karakterler, kağıt, kumaş, polimer kil ve diğer hazır malzemelerin, dikilmesi, yapıştırılması veya modellenmesi sonucunda oluşturulmuştur. Bu aşamada uygulama yöntemlerinin kendine has olanak ve sınırları ile öğrencilerin bu işlemler üzerindeki deneyim eksiklikleri tesadüfi sonuçları doğuran etkenler olarak öne çıkmıştır.

Bir sonraki aşamada hayvan yorumları farklı açılardan fotoğraflanarak, en uygun duruşun resimlemede rehber olarak kullanılmasına karar verilmiştir. Öğrenciler, işlemler sonucunda oluşan olağan ya da hatalı görünümleri de önemseyerek, modeller üzerindeki oran-orantı ve 1şığa dikkat edip resimlemelerini gerçekleştirmişlerdir. Kendi anlatım dillerine uygun resimleme tekniklerini kullanan öğrenciler renk konusunda da modelden bağımsız davranabilmişlerdir. Kitap ile ilgili çalışmaya geçilmeden önce bu aşamada son olarak tasarımı tamamlanan hayvan karakterinin, aynı resimleme yöntemi ve renk anlayışı ile insana dair bir eylemi gerçekleştirirken resmedilmesi istenmiştir.

Görsel 9'daki çalışmayı gerçekleştiren öğrenci ayı karakterini yorumlarken sert bir malzemeden kestiği yalın formun üzerini, ayı karakterinin karakteristik yapısını çağrıştıran formalara uygun kesilmiş keçe kumaşlarla kaplamıştır. Ortaya çıkan görüntü bir sonraki aşamada vektör bazlı dijital çalışma ile resmedilmiştir. Çocuk diline uygun stilize ve canlı bir renk anlayışı ile resmedilen karakter, kamp yapan bir figür olarak insanlaştırılmıştır. 

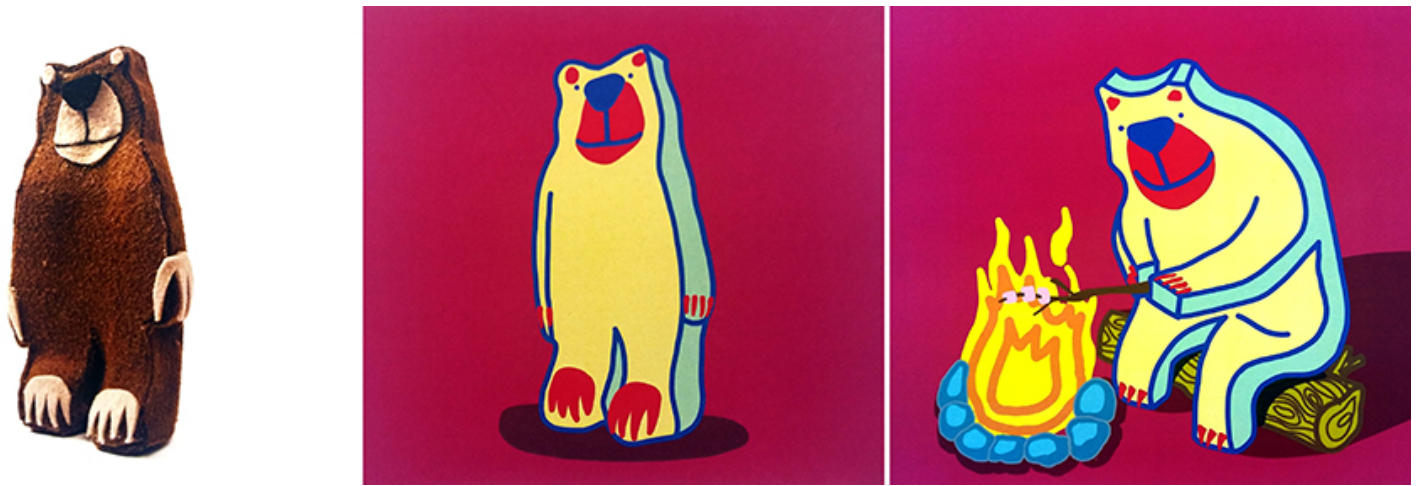

Görsel 9. Ayı karakteri için tasarım aşamaları, İbrahim Kaçtıoğlu, 2016.

Görsel 10'daki çalışmayı gerçekleştiren öğrencinin seçtiği hayvan tilkidir. Polimer kil kullanılarak biçimlendirilen karakterin rölyef etkisinde, profilden bir görünüm sergilemesi ayırt edici bir kimlik olarak öne çıkmaktadır. Tilki karakteri burun yapısı ile vurgulanmış, resimleme yöntemi olarak yine çocuk diline uygun özgünlükte kullanılan tarama tekniği olabildiğince serbest bir anlayışla ortaya konmuştur. Tilki karakterine son aşamada piyona çalan bir müzisyen olarak insansı özellikler eklenmiştir.
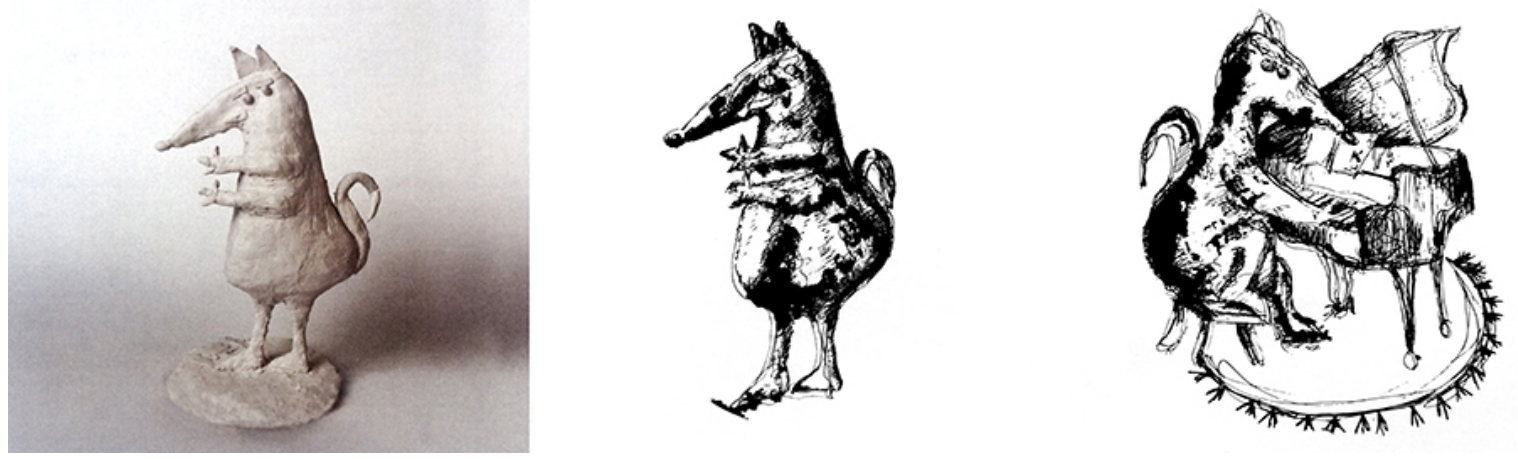

Görsel 10. Tilki karakteri için tasarım aşamaları, Şeyda Bayrak, 2016.

Görsel 11'de içi doldurulup, dikilerek oluşturulan bir zebra figürü yer almaktır. Siyah çizgileriyle karakterize edilen zebra figürünün özgün bir vücut ve baş yapısına sahip olduğu dikkati çekmektedir. Bununla birlikte dikim aşamasındaki kaba yöntem, resimlemedeki serbest tarzın ortaya çıkmasını etkileyen bir unsur gibidir. Geleneksel çizim, dijital boyama ve çeşitli dijital efektlerin harmanlandığ resimlemede gerçekçi ve yalın bir renk anlayışı tercih edilmiştir. Zebra figürü bu çalışmada dalgıç olarak insanlaştırılmıştır.
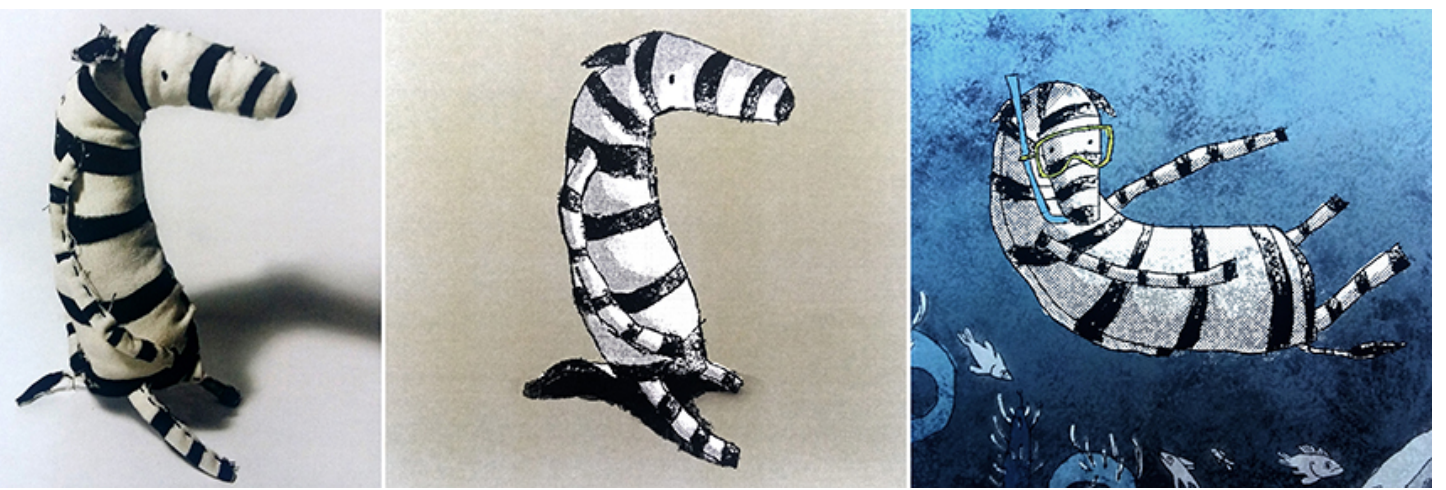

Görsel 11. Zebra karakteri için tasarım aşamaları, Gökhan Altay, 2016. 
Görsel 12'de ise burun yapısı ve kuyruk hareketiyle biçimlendirilmiş bir balina görülmektedir. Polar kumaşın içi doldurularak dikilen model, marker ve pilot kalem kullanılarak resmedilmiştir. Karakterin piyanist olarak insanlaştırılması sırasında resmedilen kıyafetler ve piyanodaki detaylar duygu durumunun etkili bir şekilde aktarılmasını sağlayan yaratıcı izlenimlerdir.
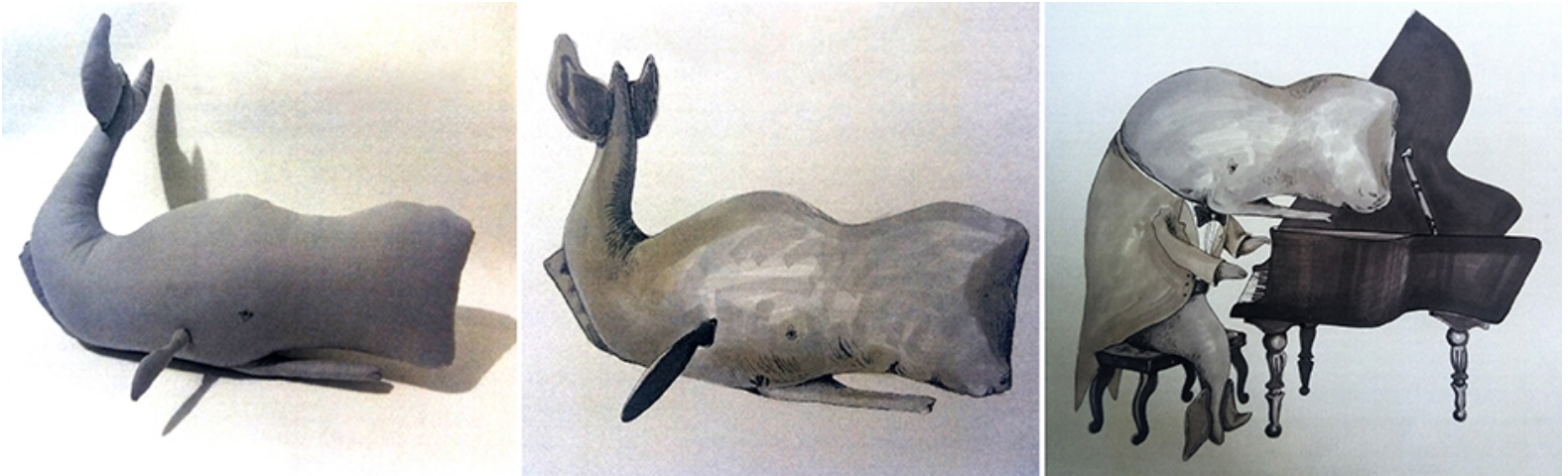

Görsel 12. Balina karakteri için tasarım aşamaları, Eren Uçak, 2016.

Gergedandan yola çıkarak yeni bir karakter tasarlamayı tercih eden öğrencinin çalışması Görsel 13'de yer almaktadır. Polimer kil kullanarak modellenen karakterin insansı bir duruşa sahip olmasının yanında, kulak yapısında da gergedan figüründen uzaklaştı̆ğ anlaşılmaktadır. Renkli kalemi kaba dokusal değerler elde edeceği bir kağıt çeşidi üzerinde uygulayan öğrenci, karakterini kitap okuyan bir figür olarak insanlaştırmayı seçmiştir.
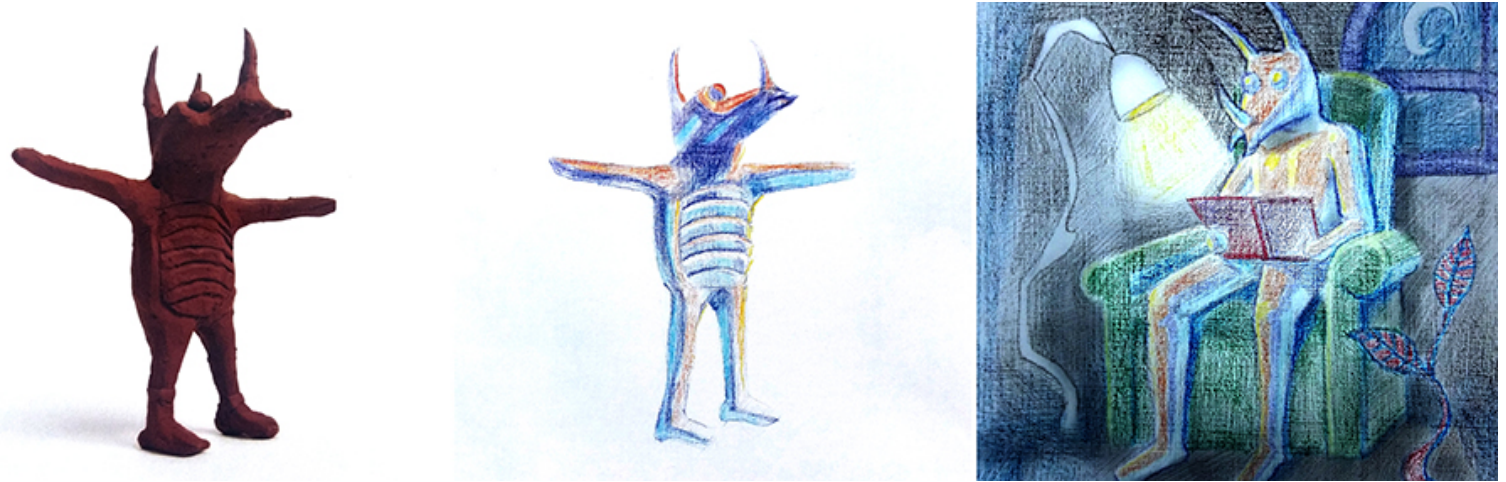

Görsel 13. Gergedan karakteri için tasarım aşamaları, Görkem Ayyıldız, 2016.

Görsel 14 'de yer alan salyangoz yorumu proje üzerindeki son örnek çalışmadır. Salyangoz karakteri biçimlendirilirken süzgeç, ip ve içi doldurularak dikilen bir kumaşın birleştirdiği görülmektedir. Ortaya çıkan karakter monotipi baskı ve pilot kalem kullanılarak son derece özgün bir forma dönüştürülebilmiştir. Salyangozun koşan bir karakter olarak insanlaştırılması düşünülmüştür.
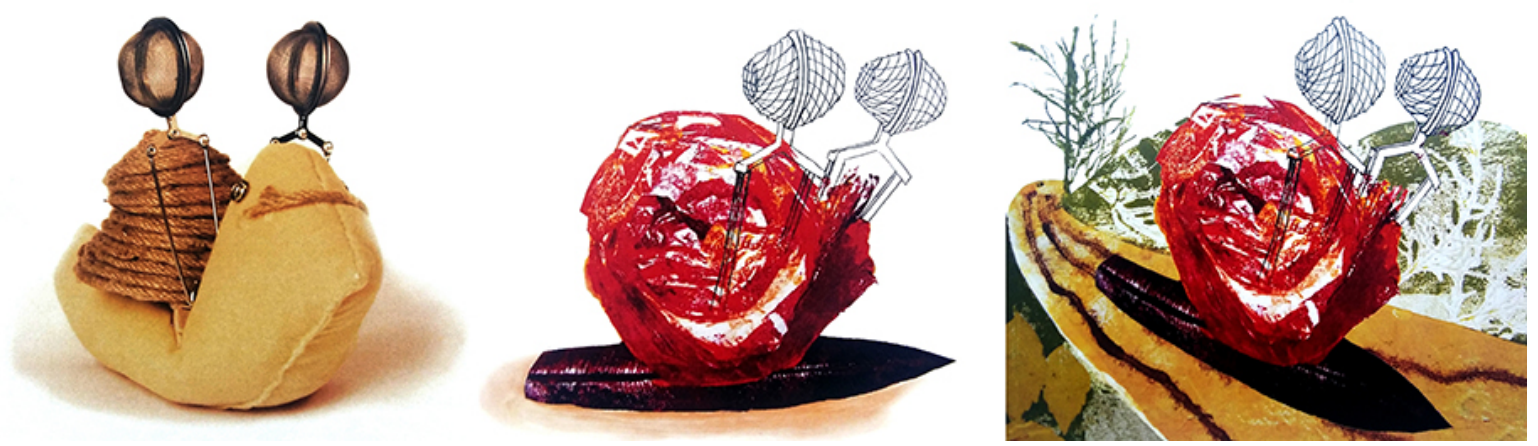

Görsel 14. Salyangoz karakteri için tasarım aşamaları, Sacide Demiral, 2016. 


\subsubsection{Kitap Tasarımı}

İllüstrasyon metnin anlamını destekleyen, açıklayıcı bir öğe olarak kullanılmaktadır. Metne eşlik eden görsel, resimleyenin hayal gücüyle içeriğin daha da zenginleştirilmiş haline dönüştürülebilir. $\mathrm{Bu}$ tespitten de yola çıarak özellikle çocuk kitaplarında metin ve illüstrasyon ikilisinin birbirini tamamlayan unsurlar olduğu söylenebilir. İllüstratör, yazara ait ifadeleri görselleştirmede tasarım problemine çözüm getiren yaratıı bir birey gibidir. Bununla birlikte illüstratörler yazarlara ait dünyayı görselleştirirken, kendi anlatımlarını da resimledikleri görülür. Öğrencilerin hikaye yazımı ile ilgili herhangi bir deneyimlerinin bulunmadığı da göz önünde bulundurularak, bu aşamanın kolaylaştırılması için bazı adımlar atılmıştır. Her şeyden önce öğrencilerden hikayelerini oluştururken karakter tasarımının son aşamasında yaptıkları insanlaştırma çalışmalarından yola çıkmaları istenmiştir. Böylelikle "konu" ile ilgili dolaylı bir yönlendirme yapılmıştır. Hikayelerin, okul öncesi dönem çocuklarına uygun içerik ve kapsamda, kısa cümleler ve fazla uzun olmayan bir metinlerden oluşturulması sağlanmıştır. Yazılan hikayelerden seçilen bir örnek şu şekildedir;

Rıfkı aylak aylak yüzmekteydi. İleride bir 1şık gördü. Merak edip ışığa doğru yüzmeye başladı. Bir süre sonra ileride gördügü büyük beyaz sşığın, aslında bir istiridye olduğunu fark etti. İstiridye nefes alır gibi hareket ediyordu. İçinde ne olduğunu merak etti ve istiridyeyi açtı. Karşılaştı̆̆ 1 şey büyük beyaz bir inci tanesiydi. Adeta bir yıldız gibi parlıyordu. Almak için dokunduğu sırada, inci tanesinin büyüsüne kapılıp hayal görmeye başladı. Hayalinde yıldızların arasında dolaşıyordu. Bir süre sonra gördüğü hayal bulanıklaşarak kayboldu. Kendine geldiğinde inciyi yanına almaya karar vermişti. Ertesi gün başka istiridyeler aramak üzere tekrar yüzmeye gitti. Dün bulduğu istiridyenin 1şığını kaybedip soluklaştığını gördü. $\mathrm{O}$ an anladı ki istiridye ve inciyi birbirinden ayırmıştı. Hemen geri dönüp bulduğu inciyi istiridyenin içine bıraktı. İstiridye artık eskisi gibi etrafına ışık saçıyordu. (Aylak Rıfkı ve İstiridye / Gökhan Altay)

Hikayenin tamamlanması ile birlikte öğrenciler altı resim (12 sayfa) için hızlı sayfa taslakları gerçekleştirmişlerdir. Bu aşamada görsel elemanların sayfa içindeki düzeni kurgulanmakla birlikte karakter tasarımından yola çıkılarak, o karaktere ait dünyanın ve diğer karakterlerin nasıl olacağına da karar verilmiştir. Metin beş ya da altı parçaya bölünüp, her bir metin parçası için resimleme yapılmış, taslaklar hazırlanırken metinler için uygun boşluklar bırakılmıştır. Orijinal resimlemeler tamamlandıktan sonra ise kapak resimlemesine geçilmiş, tüm resimlemelerin bitmesiyle tipografi çalışmasına başlanmıştır. Başlangıç sayfaları (kapak içleri ve boş sayfalar, künye sayfası ve iç kapak) tasarlanarak, tek forma (16 sayfa) halinde oluşturulan kitap projesi, maketin de yapılmasıyla tamamlanmıştır.

Görsel 15'de Ayı karakterinin ormanda yaptığı kampta "Marşmelovlar" ve "Siyahi Jelibonlar" ile tanışmasını anlatan fantastik hikâyenin kapak ve iç sayfalarından örnek bir çalışma görülmektedir. $\mathrm{Bu}$ çalışmayı resimleyen öğrencinin stilize form ile canlı renklerin hakimiyetinden oluşan bir anlayışı kitabın tamamına yansıttı $\breve{g} 1$ izlenmektedir. Bu unsurlar ile birlikte özellikle karakterler ve bu karakterler ait dünyayı pekiştiren diğer bazı çevre öğeleri üzerindeki belirgin kontur kullanımı çalışmanın bütününde kimlik saylayan bir öğe niteliğindedir.

Kaybolan bir notanın peşine düşen Tilki’ye ait maceranın anlatıldığı kitaptan örnek resimlemeler Görsel 16'da yer almaktadır. Öğrenci karakter üzerinde kullandığı serbest resimleme tarzını kitabın diline dönüştürmüş ve bu etkinin şiddetini arttırmak için siyah-beyaz resimlemeler denemiştir. $\mathrm{Bu}$ deneme ile sayfa düzeni üzerinde boşluk ve dolu alanlarla kuvvetli bir denge oluşturulduğu gibi, çocuğun hem kendi dilene uygun bir yaklaşım hem de hikayeyi tamamlamasına izin verecek bir yaklaşım sergilenmiştir. 


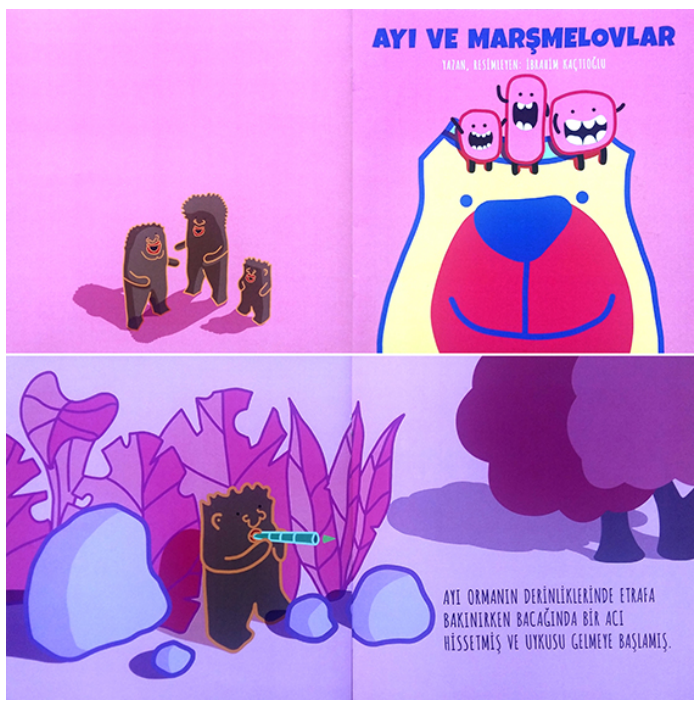

Görsel 15. “Ayı ve Marşmelovlar”kitabindan kapak ve iç sayfa resimlemesi, Ibrahim Kaçtıoğlu, 2017.

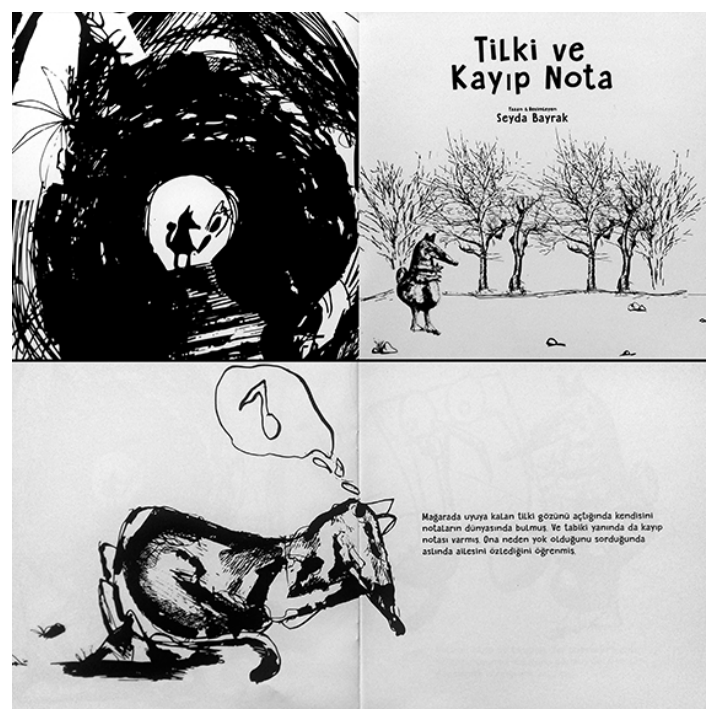

Görsel 16. "Tilki ve Kayıp Nota” kitabindan kapak ve iç sayfa resimlemesi, Şeyda Bayrak, 2017.

Görsel 17 'de daha önce tüm metni verilmiş olan çalışmaya ait kapak ve iç sayfa resimlemesinden bir örnek bulunmaktadır. Öğrenci, metnindeki düşsel kurguyu resimlemedeki uzak yakın ilişkileri ve yalın kompozisyon anlayışıyla desteklemeye çalışmıştır. Uygulama tekniğinde yer alan dijital efektlerin aşırıya kaçılmadan, yerinde kullanıldığı görülmüş ve böylece genel ambiyansa pozitif bir katkı yaptıkları anlaşılmıştır.

"Balina Paul" tek başına müzik yapmaktan sıkılan bir karakterin yeni arkadaşlarla tanışmasını anlatan bir hikayedir. Görsel 18'de kapak ve iç sayfa resimlemesinden örnek bir sayfanın yer aldığ bu hikâyenin resimlemesinde öğrenci, sıklıkla kullanılan bir uygulama yöntemi seçmekle birlikte gerek karakterin insanlaştırılması gerek karakterlerin mimik ve hareketleri gerekse de içinde bulunan duygusal atmosferi destekleyecek derecede detay kullanımı ile başarılı bir deneme yapmıştır.

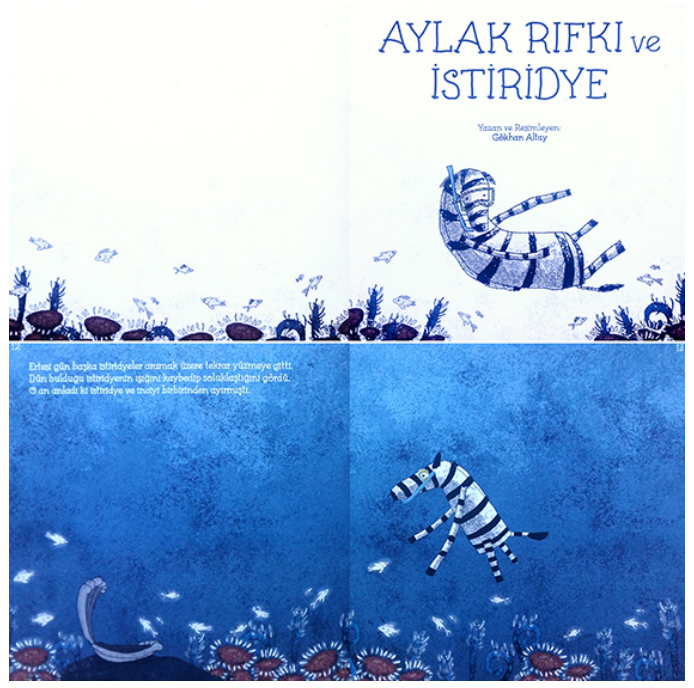

Görsel 17. “Aylak Rufkl ve İstiridye”kitabından kapak ve iç sayfa resimlemesi, Gökhan Altay, 2017.

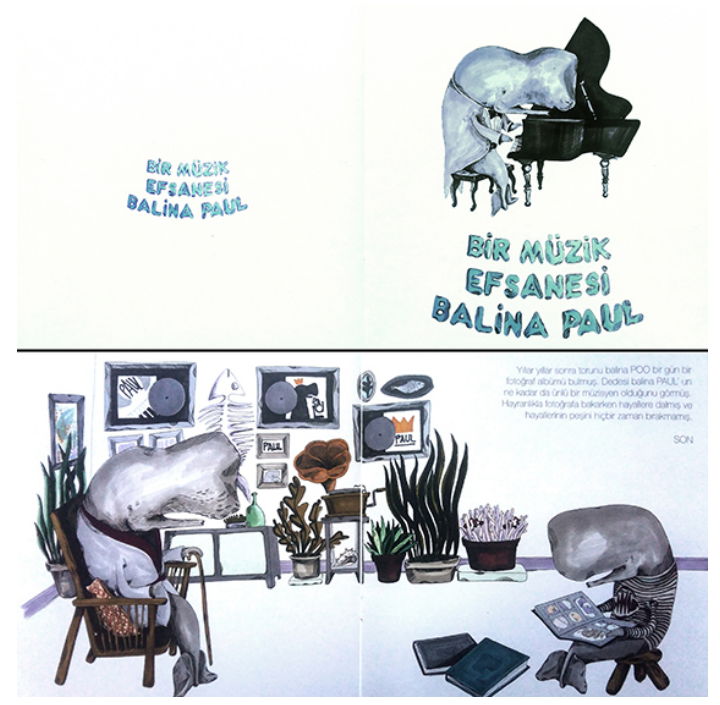

Görsel 18. "Bir Müzik Efsanesi balina Paul" kapak ve iç sayfa resimlemesi, Eren Uçak, 2017. 
Gizemli bir kutunun hikayesini okuduğumuz kitaptan örnek çalışmalar Görsel 19'da yer almaktadır. Öğrenci, karakter tasarımında ortaya koyduğu sıra dışı anlatımı, hikaye örgüsünde devam ettirmiş ve bu kurguyu destekleyecek bir kompozisyon anlayışı denemiştir. Karakterlerin yenilikçi yapısı, resimlemelerdeki yalın düzen ve öğelerin ikonik duruşu bu kurgunun parçaları olduğu gibi, bütün hayal gücünü destekleyecek özellikler sergilemektedir.

Görsel 20'de ise yavaş hareketleri ile bilinen bir salyangozun katıldığı yarış hikayesine ait kapak ve örnek sayfa resimlemeleri görülmektedir. Öğrenci geleneksel monotipi bask1 resim tekniğinin sonuçlarını dijital ortamla birleştirme üzerine denemeler yapmış ve bu denemelerin sonucunda zengin dokusal değerleri gösteren sayfa düzenlemeleri ortaya çıkmıştır. Görsel 21'de aynı çalışmanın kapak içi ile boş sayfanın değerlendirilmesi ve künye ile iç kapak tasarımları görülürken, Görsel 22'de ise diğer sayfalardan örnekler yer almaktadır.

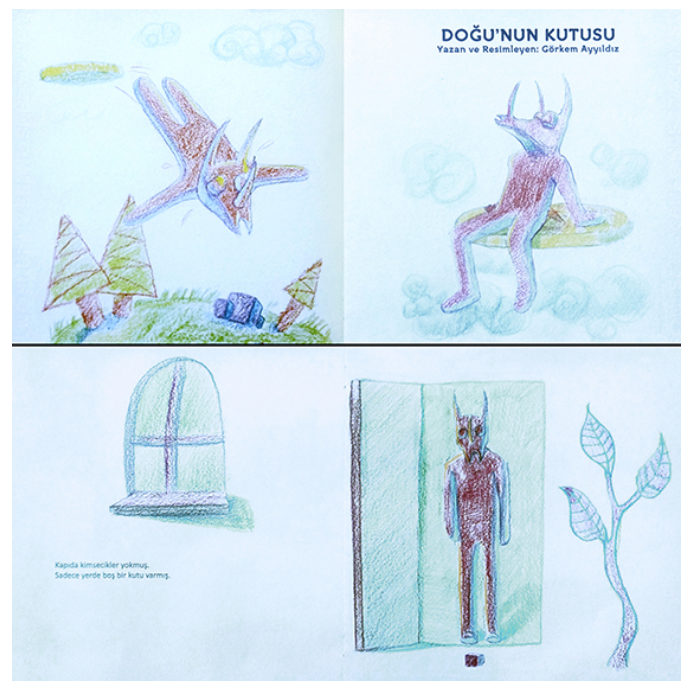

Görsel 19. “Doğu'nun Kutusu”kitabindan kapak ve iç sayfa resimlemesi, Görkem Ayyıldız, 2017.

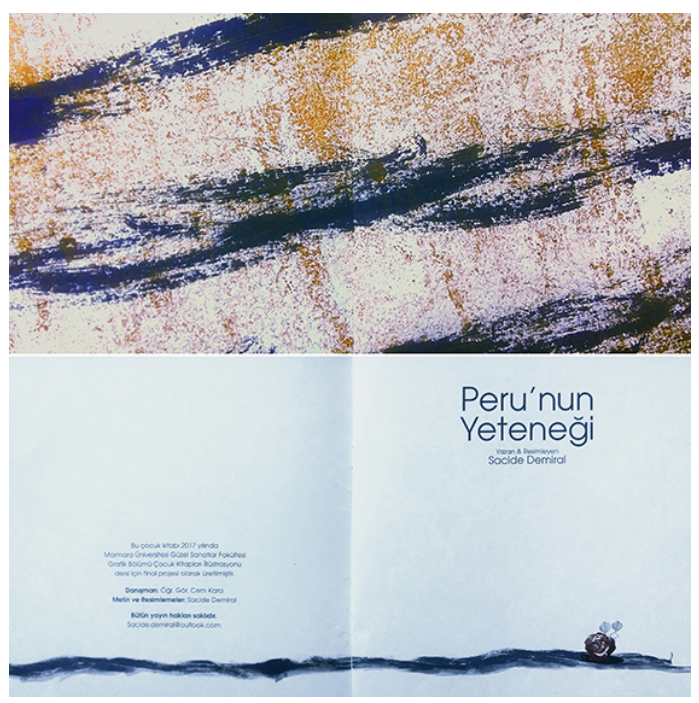

Görsel 21. "Peru'nun Yeteneği " kapak içi, boş sayfa, künye ve iç kapak tasarımlart, Sacide Demiral, 2017.
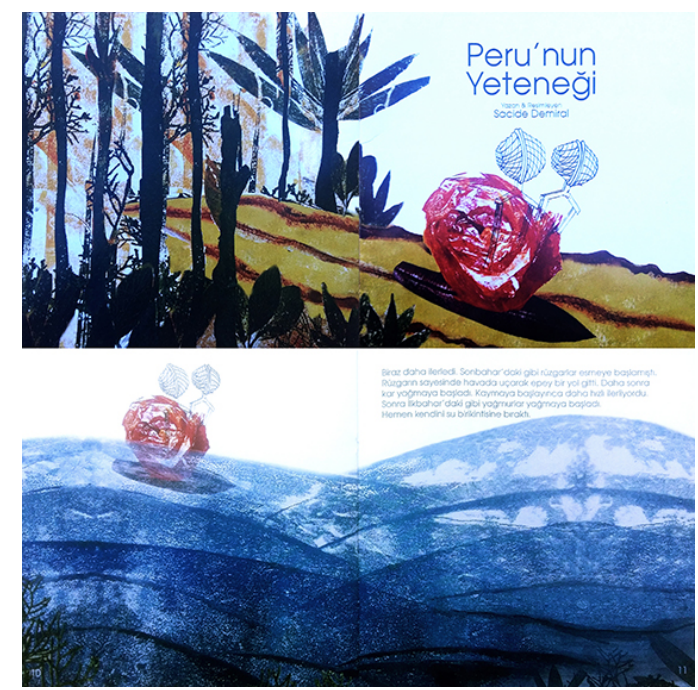

Görsel 20. "Peru'nun Yeteneği” kitabindan kapak ve iç sayfa resimlemesi, Sacide Demiral, 2017.
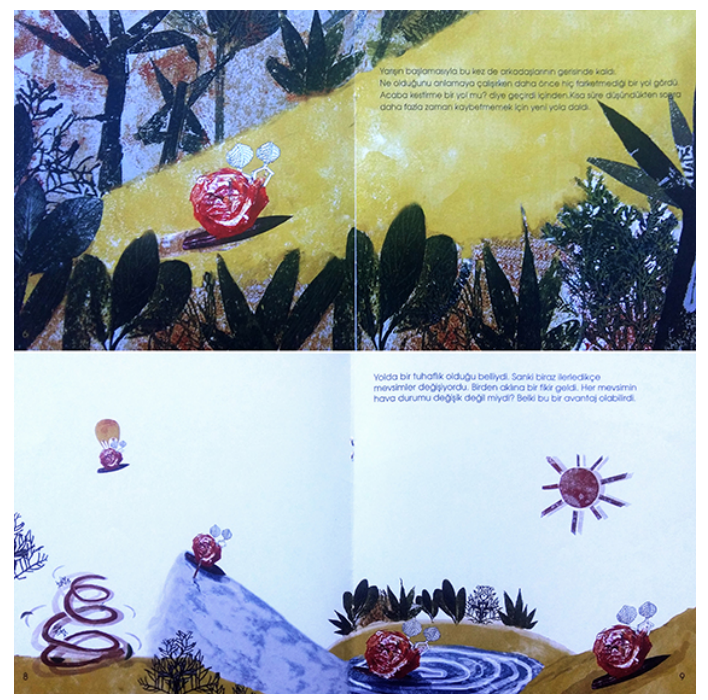

Görsel 22. "Peru'nun Yeteneği” kitabindan örnek iç sayfa resimlemeleri, Sacide Demiral, 2017. 


\section{Sonuç}

Araştırma kapsamında yürütülen Çocuk Kitapları Resimlemesi dersini daha önceki yıllarda almış olan öğrencilerin karakter tasarımı yaparken çıkış yolu bulmakta zorlandıkları dikkati çekmekteydi. Bu durumun, daha farklı bir yönlendirme yöntemi kullanılarak aşılabilmesi için planlanmış olan bu çalışmanın sonuçları, daha önceki yıllarda alınan sonuçlarla karşılaştırıldığında; önceki yıllarda öğrencilerin özgün anlatımlar geliştirmek için daha fazla çaba harcadıkları, demoralizasyon yaşayabildikleri ya da yaygın anlayışlara başvurdukları gözlemlenmiştir. Hem kişisel bir anlatım ortaya koymak hem de alanın bu yeni anlatımlarla gelişmesini sağlayacak yaratıcı çalışma hedefinden uzaklaşılarak, eğitim, projelerin tamamlanmasını önceleyen bir duruma dönüşmüştür. Çalışma sonucunda bir kez daha deneysel uygulamaların yeni ifadeler keşfetmek için verimli çalışma biçimlerinden biri olduğu anlaşılmıştır. Ayrıca başlangıçta pratiklik sağlayıp, süreç içinde de motivasyonu artıran bir yaklaşım olduğu görülmüştür. Hazır malzeme kullanmak karakterlerin biçimsel özelliklerini ortaya çıkışını olumlu yönde etkilemiş, özellikle hayvanlara ait karakteristik özellikler daha iyi analiz edilip, daha etkili stilizasyonlar, abartılar veya deformasyonlar kullanılmıştır. Malzemenin biçimlendirilmesiyle geçen süreçte, özgün tasarımlar kendiliğinden, daha kısa bir süre içinde ortaya çıkmış, ilerleyen aşamalarda ortaya çıkan model üzerinden farklı hareketlerin kurgulanmasını ve yan karakterlerin tasarlanması kolaylaşmıştır. Ancak tasarlanan modelin resimlemesinde ise aynı deneysel tavır bir kenara bırakılıp, yatkın olunan tekniklerde benzer uygulama biçimlerinin yeniden tekrar edilmesine başvurulduğu görülmüştür. $\mathrm{Bu}$ durumun oluşmasında belirleyici olan unsurlar, başta projenin belirli bir süre içinde tamamlanması gerektiği ve sonrasında zamanın planlı bir şekilde değerlendirilememesi olabilir. Elbette ki denemeci tavrın içinde çalışmayı bozma korkusu olmadan, cesaretle davranma ya da bir sonuçtan çok sürece odaklanmak yer alır.

Projeye, kitap tasarımının bütününü etkileyecek olan karakter tasarımındaki deneysel çalışmalarla başlanmış, dolayısıyla bu konuya daha fazla zaman ayrılmıştır. Karakter tasarımına verilen önem, kitap tasarımında da, karakterlerin öne çıtı̆̆ 1 sayfa kompozisyonlarını ortaya çıkarmıştır. Karakterlerin öne çıktığı istif ve boşluk kullanımı grafik etkinin kuvvetli olmasını sağlarken, karaktere ait dünya veya çevre detaylarının daha az önemsenmesine sebep olmuştur. Oysa ki aynı biçimde kompozisyon anlayışları ile birlikte, çocuğun hayal gücünü tetikleyecek bir çevre anlayışı da yarat1labilirdi.

$\mathrm{Bu}$ eylem çalışması, en önemli sonuçlardan biri olarak; çocuk kitabı resimlemesinin farklı unsurların birleşiminden oluşan bir bütün olduğunu bir kez daha göstermiştir. Çocuk kitabı resimlemesinde karakter tasarımı kadar, karaktere ait çevrenin nasıl oluşturulduğu, öğelerin sayfa içinde nasıl organize edildiği, renk anlayışı ve uygulama tekniğe ait dilin nasıl gerçekleştirildiği de ayrıca önemlidir. $\mathrm{Bu}$ tespit ile sadece karakter tasarımında değil diğer unsurla için de detaylı çalışmalar yapılacak deneysel projeler oluşturulmalı, bu deneysel uygulamalarda elde edilen deneyim ve ortaya çıkan özgün tarz, ilerleyen projeler de geliştirilerek kullanılmalıdır.

\section{Kaynakça}

Aksoy, D. (2014). Eylem araştırması: eğitimsel uygulamaları iyileştirme ve değiştirmede kullanılacak bir yöntem. Kuram ve Uygulamada Eğitim Yönetimi, 36 (36), 474-489. Erişim Adresi: http://dergipark.gov.tr/kuey/issue/10361/126837

Aş11ıŏlu, E. (2011). Grafik sanatçılarının çocuk kitaplarının grafik tasarıma ilişkin görüşlerinin değerlendirilmesi (Yüksek lisans Tezi). YÖK Tez veri tabanından erişildi (Tez no: 302013).

Aysel, K. E. (2011, 8 Temmuz). Pictoplasma: itinayla karakter tasarlanır! [Blog Yazısı]. Erişim adresi: http://www.cut-online.com/2011/07/08/pictoplasma-itinayla-karakter-tasarlanir/ 
Ball, L. (2015, 3 Haziran). Work-life balance: an interview with artist Hudson Christie [Blog Yazıs1]. Erişim adresi: https://forthmagazine.com/visual-art/2015/06/an-interview-with-hudson-christie/

Carrer, C. (2016, 21 Haziran). Picture book makers [Blog yazıs1]. Erişim adresi: http://blog.picturebookmakers.com/post/ 146250131771/chiara-carrer

Heller, S. (2017, 10 Nisan) Christoph Niemann's creative powers: a mystery investigated [Blog Yazıs1]. Erişim adresi: https://designobserver.com/feature/christoph-niemanns-creative-powersa-mystery-investigated/39672

Isidro Ferrer. (2018). The age of information, national visions within a global dialogue [Blog yazis1]. Erişim adresi: http://www.historygraphicdesign.com/the-age-of-information/national-visionswithin-a-global-dialogue/883-isidro-ferrer

Kara, C. (2017). Illlüstrasyon ögreniminde deneysel yaklaşımın önemi ve öneriler. 6. Uluslararası Marmara Üniversitesi Güzel Sanatlar Fakültesi Öğrenci Trienali Sempozyumu'nda sunulan bildiri, Marmara Üniversitesi, İstanbul. Erişim adresi: https://issuu.com/mugsf/docs/connecting_20the_20dots

Kaya, İ. (2006) Çocuk kitabı resimlerinde estetik boyut. 2. Ulusal Çocuk ve Gençlik Edebiyat1 Sempozyumu'nda sunulan bildiri, Ankara Üniversitesi, Ankara. Erişim adresi: http://kitaplar.ankara.edu.tr/dosyalar/pdf/840.pdf

Koort, M. (2015, 29 Kasım). C. Owens tarafından gerçekleştirilen röportaj [Blog yazıs1]. Interview with Malin Koort. Erişim adresi: http://bibelotmagazine.com/2018/11/29/malin-koort-interview/

Newman, R. (2018, 22 Şubat). Illustrator profile-Chris Sickels/red nose studio: Put the work out there that you want to make [Blog yazısi]. Erişim adresi: https://www.aiap.com/publications/article/21782/illustrator-profile-chris-sickels-red-nose-stu.html

Öztop, Ş. (1985, Nisan). Çocuk ve resim: duygu yoluyla eğitimden ne anliyoruz. Ankara Sanat Dergisi, 228, 16-17.

Sever, S. (2018). Çocuk ve edebiyat. İzmir: Tudem Yayın Grubu.

Şahin, G. (2014, Kış). Okulöncesi dönem çocuk kitaplarında görsel bir uyaran olarak resim. Turkish Studies Dergisi, $\quad 9 \quad$ (3), 1309-1324. $\quad$ Erişim http://www.turkishstudies.net/Makaleler/185461530_77\%C5\%9EahinG\%C3\%BCliz-edb-13091324.pdf

Tuğrul, B. ve Feyman, N. (2006). Okul öncesi çocukları için hazırlanmış, resimli öykü kitaplarında kullanılan temalar. 2. Ulusal Çocuk ve Gençlik Edebiyatı Sempozyumu'nda sunulan bildiri, Ankara Üniversitesi, Ankara. Erişim adresi: http://kitaplar.ankara.edu.tr/dosyalar/pdf/840.pdf

Yavuzer, H. (2018). Resimleriyle çocuk, resimleriyle çocuğu tanıma. İstanbul: Remzi Kitapevi.

Yoon, J. (2015, 14 Nisan). Picture book makers [Blog yazısı]. Erişim adresi: http://blog.picturebookmakers.com/post/ 116379961701/joohee-yoon

\section{Görsel Kaynakçası}

Görsel 1. Yoon, J. (İllüstratör). (2015). Beastly Verse, Enchanted Lion Books [Çocuk Kitab1 Resimlemesi]. Erişim adresi: http://blaine.org/sevenimpossiblethings/?p=3750

Görsel 2. Carrer, C. (İllüstratör). (2010). Un Dia, Petra Ediciones [Çocuk Kitabı Resimlemesi]. Erişim adresi: http://blog.picturebookmakers.com/post/146250131771/chiara-carrer 
Görsel 3. Koort, M. (İlüstratör). (2011-2018). Paper People [Kişisel Çalışma]. Erişim adresi: https:// www.malinkoort.se/\#/paperpeople/

Görsel 4. Ferrer, I. (İllüstratör). (2006). Una casa para el abuelo, Ediciones Sins entido [Çocuk Kitabı Resimlemesi]. Erişim adresi: http://www.isidroferrer.com/index.php?/bibliografia/una-casapara-el-abuelo/

Görsel 5. Sickels, C. (İllüstratör). (2010). Here Comes The Garbage Barge!, Schwartz \& Wade [Çocuk Kitab1 Resimlemesi]. Erişim adresi: https://www.nytimes.com/2010/11/07/books/review/ Schoemer-t.html

Görsel 6. Christie, H. (Illüstratör). (2017). My Sister Is a Martian, Design by Toko [Kitap Resimlemesi]. Erişim adresi: http://www.hudsonchristie.com/illustration

Görsel 7. Sachs, J. (İllüstratör). (2018). Kişisel Çalışma [Dijital Resimleme]. Erişim adresi: https://www.jacksachs.co.uk/Personal-2018

Görsel 8. Niemann, C. (İllüstratör). (2017). Sunday Sketching, Abrams [Albüm]. Erişim adresi: http://www.christophniemann.com/books/sunday-sketching/

Görsel 9. Kaçtıŏlu, İ. (Öğrenci). (2016). Ayı Karakteri [Model çalışması ve Resimleme]. Marmara Üniversitesi Güzel Sanatlar Fakültesi Grafik Bölümü Arşivi.

Görsel 10. Bayrak, Ş. (Öğrenci). (2016). Tilki Karakteri [Model çalışması ve Resimleme]. Marmara Üniversitesi Güzel Sanatlar Fakültesi Grafik Bölümü Arşivi.

Görsel 11. Altay, G. (Öğrenci). (2016). Zebra Karakteri [Model çalışması ve Resimleme]. Marmara Üniversitesi Güzel Sanatlar Fakültesi Grafik Bölümü Arşivi.

Görsel 12. Uçak, E. (Öğrenci). (2016). Balina Karakteri [Model çalışması ve Resimleme]. Marmara Üniversitesi Güzel Sanatlar Fakültesi Grafik Bölümü Arşivi.

Görsel 13. Ayyıldız, G. (Öğrenci). (2016). Gergedan Karakteri [Model çalışması ve Resimleme]. Marmara Üniversitesi Güzel Sanatlar Fakültesi Grafik Bölümü Arşivi.

Görsel 14. Demiral, S. (Öğrenci). (2016). Salyangoz Karakteri [Model çalışması ve Resimleme]. Marmara Üniversitesi Güzel Sanatlar Fakültesi Grafik Bölümü Arşivi.

Görsel 15. Kaçtıŏlu, İ. (Öğrenci). (2017). Ayı ve Marşmelovlar [Çocuk Kitabı Resimlemesi]. Marmara Üniversitesi Güzel Sanatlar Fakültesi Grafik Bölümü Arşivi.

Görsel 16. Bayrak, Ş. (Öğrenci). (2017). Tilki ve Kayıp Nota [Çocuk Kitabı Resimlemesi]. Marmara Üniversitesi Güzel Sanatlar Fakültesi Grafik Bölümü Arşivi.

Görsel 17. Altay, G. (Öğrenci). (2017). Aylak Rifk1 ve İstiridye [Çocuk Kitabı Resimlemesi]. Marmara Üniversitesi Güzel Sanatlar fakültesi Grafik Bölümü Arşivi.

Görsel 18. Uçak, E. (Öğrenci). (2017). Bir Müzik Efsanesi Balina Paul [Çocuk Kitabı Resimlemesi]. Marmara Üniversitesi Güzel Sanatlar Fakültesi Grafik Bölümü Arşivi.

Görsel 19. Ayyıldız, G. (Öğrenci). (2017). Doğu’nun Kutusu [Çocuk Kitabı Resimlemesi]. Marmara Üniversitesi Güzel Sanatlar Fakültesi Grafik Bölümü Arşivi.

Görsel 20. Demiral, S. (Öğrenci). (2017). Peru'nun Yeteneği [Çocuk Kitabı Resimlemesi]. Marmara Üniversitesi Güzel Sanatlar Fakültesi Grafik Bölümü Arşivi.

Görsel 21. Demiral, S. (Öğrenci). (2017). Peru'nun Yeteneği [Kitap Tasarımı]. Marmara Üniversitesi Güzel Sanatlar Fakültesi Grafik Bölümü Arşivi. 
Görsel 22. Demiral, S. (Öğrenci). (2017). Peru'nun Yeteneği [Çocuk Kitabı Resimlemesi]. Marmara Üniversitesi Güzel Sanatlar Fakültesi Grafik Bölümü Arşivi. 